\title{
Change and continuity in the techniques and technologies of identification over the second Christian millennium
}

\author{
Edward Higgs
}

Received: 19 June 2009 / Accepted: 15 October 2009 /Published online: 17 November 2009

(C) The Author(s) 2009. This article is published with open access at Springerlink.com

\begin{abstract}
This paper looks at the history of identification in England over the past 1,000 years. It contends that techniques and technologies of identification do not identify a single entity but a number of forms of personality, including the juridical person, the citizen and the deviant. Individuals can be the bearers of more than one of these personalities at the same time, or over the course of their life. These personalities are created by social performances to which people are trained to react conventionally. As such identity, and its identification, is a social and cultural phenomenon, rather than a 'thing'. Each of the personalities noted above has been identified historically in differing ways -through possessions or techniques in the case of the juridical person, though the community in the case of the citizen, and on, or through, the body in the case of the deviant. In the contemporary world these distinctions are being effaced, as all forms of identification are being reduced to the body and the database. This levelling of social forms of being has implication for what it means to be a person in our society, and for public perceptions of new techniques and technologies of identification.
\end{abstract}

Keywords History of identification - Identification of juridical persons - Identification of citizens $\cdot$ Identification of criminals $\cdot$ Seals $\cdot$ Signatures $\cdot$ Fingerprints $\cdot$ DNA

\section{Introduction}

The best service an historian can offer to a workshop concerned with the impact on contemporary identity of new technologies of identification is to put some of our present-day concerns into a broader temporal framework, and to ask what is new and what has not changed. I also want to interrogate what exactly we mean by identification-identification of what exactly? I am going to do this by 
looking at identification in one society, England, over the past 1,000 years. This is partly because it is what I know best but also because it would be impossible to examine the whole of world history for a millennium. I am going to define 'techniques and technologies of identification' in a very broad manner, as those practices and artifacts that have been used to identify the person. Note here the use of the term 'person', which can mean both the individual human body and the different modes of being possible in a society. The term 'person' after all comes from the Latin 'persona', the mask worn by actors in a play, and historically different forms of identification have been used to identify juridical persons, citizens, and deviants.

Now at first sight the argument that we can study the identification of something other than the body seems odd. Doesn't identification identify bodies that have unique experiences? This is certainly New Labour's justification for spending billions of pounds on a national biometric ID system. However, such an approach is somewhat problematic because forms of identification, seals or signatures for example, have been able do things long after the body has simply ceased to exist. An early-modern will, for example, could establish an entail to prohibit the passage of an estate outside a very narrowly defined set of descendents - the eldest son of the eldest son, and in default the eldest son of the eldest brother, and so on. In this manner a will could project rights and obligations over generations, so what exactly did the seal or signature on it identify? If the will or intention of a person can be identified, and yet be dissociated from the physical presence of the body that can will or have intentions, then surely something else is going on. An additional complication here is, of course, that many pre-modern records were not signed or sealed by individuals themselves - they made a mark, or they were 'signed' by notaries. So how does identification function here?

One of the most fruitful ways to approach these issues is through the work of the great Canadian sociologist Erving Goffman. For Goffman society is a system in which individuals play conventional roles, which others are taught to understand in certain ways, and to which they also respond in a similarly conventional manner. As he argued in 1959 in The Presentation of Self in Everyday Life, when we meet a stranger it is necessary to know who he or she is so that we know how to react in the correct manner. We are programmed to react differently to a demand for money when the person making the demand is a beggar, rather than a tax inspector. But it is not possible to know all the facts of the situation, so we have to rely on cues, tests, hints, expressive gestures, status symbols, the possession of certain artefacts, and so on, as predictive devices. It is necessary to present credentials and tokens, or perform some act, or supply some information, which carries credence.

Often this means using techniques or technologies that prove that we fall into a particular status group but frequently such activities involve proving that we are a specific person to which certain rights and obligations are attached. The attachment of certain types of rights and obligations to particular bodies through the social processes of identification is what creates their social personality, as juridical persons and as citizens. The individual who fails to perform in the correct manner is often placed outside society as a deviant, and has an identity forced upon him or her through the body. Identity, in this sense, is not something that resides in individuals but in the social interactions in which they take part. It is these performances that 
identify differing personalities, in what Goffman calls 'front stage', rather than some essential, authentic 'self', or the materiality of the body. Since identification of the person, as opposed to the body, resides in the acceptance of performances, then these performances (the application of a seal to a document, for example) can have social effects in time and space even though the body is not present, or no longer existsthe personality is different to the body and outlasts it as long as performances in the past are accepted in the present.

However, the necessary performances cannot simply be in terms of an assertion to others that 'I am Edward Higgs', since anyone could do that. As my colleague Jane Caplan has pointed out, identification would then become a tautology-saying 'I am I' (Caplan 2001). Beyond immediate kin and community, where one is known via shared experience, the 'other' to which one performs often means an entity that exists over time and space, such as the State, or commercial organisations. Identification before such entities usually involves an act of authority - the State or company declares that one has proven to it in some sense that 'You are X'. Then a token of this identification is given to the person that can be compared to a stored version of that original act of identification at a different time or place. Seeing identification in these terms also explains how persons who could not identify themselves through signatures or seals in the pre-modern period could give a certain illocutionary force to their utterances - they are given a juridical personality through their avowals of identity being recognised by the State. Hence the role in the establishment of property rights in England of the enrolment of deeds and testamentary documents in courts of law. On the Continent this was often done via recognition by a public notary.

\section{Identifying the juridical person}

Having now laid this groundwork, I want to look at the identification of the three personalities - juridical person, citizen, criminal (a sort of anti-personality) — in turn. How has the development of techniques and technologies of identification informed identity? Let us take the juridical person first. Until well into the nineteenth century many, if not most, credit transactions were performed orally before witnesses. This was, of course, a highly problematic way of doing business since the identification of the will of the parties depended on the veracity of those witnesses. This helps to explain the highly litigious nature of early-modern society. It has been calculated that by the late sixteenth century the amount of civil litigation in England might have been as high as 1,102,367 cases per year, one suit for every household in the country, although this level subsequently declined as people became more accustomed to dealing with large amounts of credit. This can be compared to England and Wales in the mid 1990s when the rate of civil litigation was only a quarter of this figure (Muldrew 1998).

From the early medieval period more permanent and irrefutable means of identifying the will of the juridical person were being developed, especially the use of the seal matrix to impress a wax seal on a document. Seal matrices had the power to represent the personality of their possessors - they were not necessarily simple utilitarian objects. Indeed, Brigitte Bedos-Rezak has argued that in the early 
medieval period the seal partook, in some sense, of the person of its owner. The early medieval debates about the nature of the Eucharist developed the idea that reality was capable of being embodied through an iconic convention. Thus, the bread and wine were the body and blood of Christ - 'to be like' became 'to be part of' (Bedos-Rezak 2000). As a result, the impression of the owner's symbol in the wax of the seal could embody his person in the artifact. Seals could even speak in the first person with inscriptions such as TEGO SECRETA FRANGE L[EGE] ('I cover secrets. Break [me and] read'). The ability of the seal matrix to create its mirror image in wax inevitably associated it with magic and the occult (Clanchy 1993a).

On the other hand, in the early middle ages the signature, or sign manual, was not accepted by itself as a lawful symbol of authentication on a document. A Christian was required to either sign with a cross, indicating that he was making a promise in the sight of Christ crucified, or more commonly he affixed to the document his signum in the form of a seal. This did not apply if the signatory was a Jew, who could not, for obvious reasons, make the sign of the cross (Clanchy 1993b). The sign manual, or autograph signature, became more common in the later Middle Ages. It was used by Edward III as early as 1362, but probably because it was the custom of the King of Castile to whom he was writing. Although the practice spread rapidly in England in the late fourteenth and early fifteenth centuries, even in the $1400 \mathrm{~s}$, when the sign manual was in common use, seals were still used on formal documents (Harvey and McGuinness 1996a). Gradually a 'mixed economy' of forms of identification seems to have developed to identify the juridical person. In 1509, for example, Henry VII attested his will with his sign manual, his great seal, his privy seal, the signet seal that was kept by a secretary, and the privy signet seal with an eagle, which he kept himself (Harvey and McGuinness 1996b). By the seventeenth century, seals were often accompanied by signatures on documents, and the latter increasingly took precedence. Thus, Charles I's death warrant was both signed and sealed by 59 commissioners, although one of the seals of the regicides (appropriately that of Oliver Cromwell) was actually used twice (Jenkinson 1968). By the eighteenth century, the 'seal' was often reduced to an unstamped blob of wax that accompanied a personal signature for form's sake, although large formal seals continued to be used by the Crown, corporations, and municipalities.

So why did the signature eventually replace the seal? Only some very tentative answers to this question are possible here, given the relative lack of research undertaken on the subject. However, it is probably not the case that this represented simple technological determinism - the replacement of a poor technology by a better one. Indeed, in the High Middle Ages the seal probably did a better job of identifying the personality than the signature that replaced it in the early modern period. It is possible that $40 \%$ of the population of England had access to a seal in the thirteenth century, whilst perhaps only $10 \%$ of men could sign their names in 1500 (Clanchy 1066-1307; Hilton 1969; David 1980). The shift between medieval period and the seventeenth century from a peasant society to one where the majority of people were landless labourers, may have led to a declining need for individuals to identify themselves in legal documents. It is possible that the ability of the seal to 'embody' the person, as Bedos-Rezak has argued, declined in Reformation England along with the acceptance of other forms of embodiment, such as the Roman Catholic Church's belief in transubstantiation. The outward show of the sign was 
replaced by the signature that was supposed to reveal traits of character and penmanship - the inner man, rather than the outward show. Béatrice Fraenkel, discussing the development of the signature in France, has seen this development in terms of the 'importance progressively accorded to the singularity of the subject', and the development of individualism from the sixteenth century onwards (Fraenkel 1992). One might see this in terms of either the development of 'possessive individualism, or of the need of the state to individualise its subjects for the purposes of control (Macpherson 1962; Foucault 1991). But, of course, Fraenkel is writing about a country that remained Roman Catholic, so one might expect there to be little change if the signature is associated in some way with the changes associated with the Reformation. There is plainly much more research that needs to be done here.

Despite all the vast social upheavals since the early-modern period-the Industrial Revolution, population increase, urbanisation, and so on - there was actually very little change in the manner in which the juridical person was identified in England until the 1960s. This seems to cast doubts on the assumed association between the development of new techniques and technologies of identification, and the onset of 'modernity'. What happened in the 1960s, and in the following decades, was that banking in England began to be automated, with the introduction of automatic machine tellers (ATMS) and the development of electronic point of sale (EPOS) systems. There seem to have been several reasons for these developments. First, the banks were worried that the expansion of personal banking then taking place would lead to the collapse of the clearing house system based on the circulation of signed paper cheques. They also wanted to provide new services to customers because they were afraid that the Wilson government's proposal to turn the Post Office into a rival banking system via GiroBank would undermine their business. In addition, successful trade union activity amongst banking staff had curtailed the opening hours of banks, and bankers wanted to allow customers to obtain cash outside working hours (Ackrill and Hannah 2001; Vine 1967; Clearing bank serviceswhere the problems lie 1971; New Banking Moves to Counter Giro 1967).

These developments, which have been taken further by the development of online banking, radically changed how legal persons identified themselves in business transactions. The customer now has to provide a bank with information for an authoritative identification, and in return is provided with cards that are tokens of their identity. To use the cards the customer has to supply information such as a PIN number, which is a common key known to both the bank and the customer. In internet banking there may also be passwords and 'significant phrases' that are held in common by the two parties. If the customer has a problem and needs to prove their identity, then they have to do this by providing information that can be compared to the information supplied at the time of the original act of authoritative identification by the bank. What this means, of course, is that identity no longer depends solely on the possession of an artifact, such as a seal, or the ability to do something, such as writing one's signature. Identification now resides, for all intents and purposes, in computer databases, in a sort of digital doppelgänger to which the 'real' person has to claim a relationship through providing information (Solove 2004). Because identification now resides outside the person, it can be more easily stolen, which helps to explain the $£ 1$ billion plus losses through identify fraud in the 
UK each year (Identity Fraud: a Study 2002). In the past, seals and signatures could be forged but forgeries could, and frequently were, spotted. But now if one's identity is stolen, the thief has actually become you. This uncertainty about the possession of one's own identity may help to feed that ontology of fear that is omnipresent in the contemporary world (Svendsen 2008).

\section{Identifying the citizen}

'Citizenship' is a contested term, made more complex in Britain because of the fiction that we are subjects of the Crown. However, for the purposes of this paper I will define citizenship as simply the ability to claim rights within a political system. Today we have many such rights in Western democracies, especially the right to vote, but in England rights, especially to welfare, long preceded the winning of the franchise in the course of nineteenth and twentieth century. Under the Tudor and Stuart Poor Laws, the respectable poor had a right to relief via a local tax if they could prove that they 'belonged' to a parish. Indeed, the Poor Law assumed that everyone was, or ought to be, a known member of a parish, either though birth, employment or continued residence for a certain period. Proving a 'settlement' for Poor Law purposes depended on the personal knowledge of the local overseers of the poor, or of the 'ancient members' of the community, or the ability to produce documentation, such as a baptismal entry in a parish register, or a certificate from magistrates in another parish indicating that one had a settlement there (Hindle 2004; Hindle 2006; Snell 1992). From the 1830s onwards parish registration was replaced by civil registration but this was still based on kin or neighbours identifying a person before a local registrar (Higgs 2004a). The long continuance of the Poor Law system, parts of which survived until the Second World War, may help to explain the extraordinary parochialism of the English identity down into the twentieth century (Snell 2003).

The elaboration of a central Welfare State from the Edwardian period onwardsold age pensions were introduced in 1908 and national insurance in 1911-did not change the techniques used to identify the citizen. The two main means of identifying welfare claimants were still the 'recommender system', and the cross checking of documents. The former involved some person with official status in the local community countersigning the application forms of claimants to vouch for their identity and the information they supplied. By the 1930s those claiming pensions from the Ministry of Pensions had to obtain a 'Life Certificate' proving their identity, which was to be attested by either a minister of religion, a magistrate, a physician or surgeon, an officer of HM services, a secretary of a friendly society, a postmaster or mistress, a police officer, a civil servant earning more than $£ 200$ a year, a solicitor, a bank manager, an accountants, a head teacher, or a chief area officer of the Ministry of Pensions. ${ }^{1}$

The cross-referencing of official documents was also introduced at an early stage in this nascent Welfare State. By 1912 census records from the mid-nineteenth century held at the Public Record Office were being used to check the age of old age

\footnotetext{
${ }^{1}$ National Archives, London: PIN15/2594 Identification of Pensioners 1929-1939
} 
pension applicants who had been born before the introduction of compulsory birth registration in $1874 .^{2}$ Today the documentary technique of identification has generally superseded the recommender system, with modern benefit offices requiring a vast range of documents for checking, including:

Valid Passport/ID card

Two or more passports if of dual/multinationality

Home Office documents

Work Permit

Letter from employer/contract of employment

Evidence of actively seeking work

Payslips

Mortgage/rental agreement of letter confirming where residing

Marriage/birth certificate/deed poll

Student loan documentation

Certificate of incorporation

Memorandum of association

Articles of association

Stock transfer form

Schedule D Taxation form

Services contract

Invoices

Letter from accountant

Letter from clients

Letter from college, including details of type and length of course and weekly hours

Student ID card

Full driving licence (Social Security Office 2003).

Many of these documents can, of course, be cross-referenced with each other, and with the electoral register, that great fall-back for all official forms of identification. As in the case of the juridical person, individual identification no longer depends on the personal knowledge of the community but upon one's own knowledge, or the possession of documentation that can be linked with official or commercial information systems.

\section{Identifying the criminal}

What is important to note here is that neither the juridical person nor the citizen were identified through the physicality of the body. Until very recent times, the Christian West has always tended to regard the marking of the body for the purpose of identification as indicating infamy, drawing in part upon holy scripture, Leviticus,

\footnotetext{
${ }^{2}$ National Archives, London: T1/11491 London County Local Pension Committee. Verification of ages of claimants to old age pensions by making available for public examination of records, primarily Census Enumeration Books, at the Public Record Office. 1912
} 
19:28, 'Ye shall not make any cuttings in your flesh for the dead, nor print any marks upon you: I am the Lord'. In the Classical world branding and tattooing had been associated with criminals and slaves, whilst in the Renaissance period although tattooing and cutting the stigmata into the flesh could have religious significance, bodily forms of marking were generally associated with heretics or beggars. The Christian body was the temple of the soul, and, as such, sacrosanct (Gustafson 2000).

It should come as no surprise, therefore, that branding and ear-boring, as a means of marking the deviant status of the criminal, was a statutory punishments in England from the late fourteenth century. A labour statute of 1361 declared that fugitives were to be branded on the forehead with ' $F$ ' for 'falsity'. The Vagabonds Act of 1547 ordered that vagrants, that is those poor people who had no fixed abode, should be branded with a ' $\mathrm{V}$ ' on their breast. Ear-boring was introduced in 1572, when a statute was passed requiring all vagabonds to be 'grievously whipped and burned through the gristle of the right ear with a hot iron.' By an Act of 1604, incorrigible rogues were to be 'branded in the left shoulder with a hot burning iron of the breadth of an English shilling with a great Roman " $R$ " upon the iron' (Beier 1985). Such marking of the skin might be associated with other forms of mutilation. Thus, the seventeenth-century Puritan William Prynne, who was punished for writing pamphlets against Archbishop Laud, had his ears cut off and his nose slit, as well as being branded with 'SL' ('seditious libeler') on his cheeks (Lamont and Prynne 1600-1669). Similarly, at the Old Bailey, convicts who successfully pleaded benefit of clergy, and those found guilty of manslaughter instead of murder, were branded on the thumb (with a "T" for theft, "F" for felon, or "M" for murder), so that they would be unable to receive this benefit more than once. ${ }^{3}$

However, in line with the general shift noted by Michael Foucault from punishing the body to punishing the mind (Foucault 1977), such disciplinary practices began to be phased out in the late eighteenth century. Branding as a punishment for those receiving benefit of clergy in England ended in 1779, and the last convict sentenced to branding at the Old Bailey received the sentence in $1789 .^{4}$ However, in the nineteenth century and early twentieth centuries the identification of deviancy on the body was replaced by identification of the deviant through the body. Photography began to be used to identify convicts in the 1860s. A system for taking and recording the unique bodily measurements of criminals, anthropometrics, was introduced into England from France in the 1880s. This was replaced, in turn, by forensic fingerprinting when Sir Edward Henry, who had developed the modern fingerprint classification system in India, joined the Metropolitan Police in 1901 (Higgs 2004b). Such corporeal forms of identification were later supplemented by serology (the identification by blood groups), and by DNA profiling (Farr 1979; Williams et al. 2004).

However, despite the obvious uses of such biometrics in the identification of criminals, their application to the 'respectable' has always been resisted by the

\footnotetext{
${ }^{3}$ Proceedings of the Old Bailey Website: http://www.oldbaileyonline.org/static/Punishment.jsp\#branding (10/10/2008).

${ }^{4}$ Proceedings of the Old Bailey Website: http://www.oldbaileyonline.org/static/Punishment.jsp\#branding $(10 / 10 / 2008)$.
} 
British public. In the nineteenth century the British Army tried to identify soldiers by vaccinating them on the inside of the arm, and through the use of anthropometrics. But these methods were soon abandoned because, in part, their use threatened military recruitment. In 1902 a War Office committee rejected the use of fingerprinting to identify new recruits for similar reasons. ${ }^{5}$ In the aftermath of the First World War, a Treasury proposal to identify all state pensioners via fingerprinting was rejected by the War Office and the Ministry of Pensions, on the grounds of possible public hostility to the more general use of techniques of identification associated with criminality. ${ }^{6}$ Similarly, the identity card introduced for private citizens during the Second World War carried no form of identification other than a signature, on the grounds that fingerprints or photographs might create resistance to the ID card system (Vivian 1951). The modern British passport, of course, carried a photograph from its inception in 1915 but this was a liminal document to identify individuals crossing the border of states (Torpey 2001). In this light, the contemporary concerns over the preservation on police databases of samples of DNA from non-criminals, and some of the opposition to biometrics on the proposed UK ID card, reflect deep cultural assumptions about what forms of identification are permissible in society. People seem quite happy to use biometrics to identify themselves in the private or commercial sphere-hence the increasing use of fingerprint scanners on laptops and the like. But when dealing with the State, bodily identification is associated with deviancy.

\section{Conclusion}

The conclusion to be drawn from this analysis is that the techniques and technologies of identification have always been implicated in the formation and perception of identity in society. The identities of the multiple personalities we claim, or can have thrust upon us, are formed through social interactions mediated by techniques and technologies. But this mediation cannot simply be understood in terms of the functioning of such technologies, or the imposition of authority. How one technology of identification replaces another can be a long, drawn out process that takes centuries, and may not lead to wider or better identification. Similarly, the imposition of new technologies of identification can be resisted if they threaten entrenched social practices and self-identities. The reaction to such technologies cannot be understood in terms of their own functionality or efficiency, since they operate within a network of social process and assumptions.

Open Access This article is distributed under the terms of the Creative Commons Attribution Noncommercial License which permits any noncommercial use, distribution, and reproduction in any medium, provided the original author(s) and source are credited.

\footnotetext{
${ }^{5}$ National Archives, London: WO32/8708 Proposals for more stringent check on previous history of candidates for enlistment: Precis for the Army Council No. 476, 'Adoption of the finger-print system in the Army to prevent fraudulent enlistment, October 1910'; National Archives, London: WO 33/229 Report of Committee on identification by fingerprints 1902.

${ }^{6}$ National Archives, London: T1/12500/10570/1920. Method of identification of pensioners: observations by various Government departments on proposals to revise the system. 1920.
} 


\section{References}

Ackrill M, Hannah L. Barclays: the business of banking 1690-1996. Cambridge: CUP; 2001.

Bedos-Rezak BM. Medieval identity: a sign and a concept. Am Hist Rev. 2000;105:1503.

Beier AL. Masterless men: the vagrancy problem in England 1560-1640. London: Methuen; 1985. p. $159-60$.

Caplan J. This or that particular person; protocols of identification in nineteenth-century Europe. In: Caplan J, Torpey J, editors. Documenting individual identity: the development of state practices in the modern world. Oxford: Princeton University Press; 2001. p. 49-66.

Clanchy MT. From memory to written record: England 1066-1307. Oxford: Blackwell; 1993a. p. 314.17.

Clanchy MT. From memory to written record: England 1066-1307. Oxford: Blackwell; 1993b. p. 128.

Clanchy. From memory to written record: England 1066-1307. p. 51.

Clearing bank services - where the problems lie. The Banker. 1971;121:395-401.

David Cressy. Literacy and the social order: reading and writing in tudor and stuart England. Cambridge: CUP; 1980. p. 176.

Farr AD. Blood group serology - the first four decades (1900-1939). Med Hist. 1979;23(2):215-26.

Foucault M. Discipline and punish: the birth of the prison. London: Allen Lane; 1977.

Foucault M. Governmentality. In: Burchell G, Gordon C, Miller P, editors. The Foucault effect: studies in governmentality. London: Harvester Wheatsheaf; 1991. p. 87-104.

Fraenkel B. La Signature: Genèse d'un signe. Paris: Gallimard; 1992.

Gustafson M. The tattoo in the later Roman Empire and beyond. In: Caplan J, editor. Written on the body. The tattoo in European and American history. London: Reaktion Books; 2000. p. 17-31.

Harvey PDA, McGuinness A. A guide to British medieval seals. London: British Library and Public Record Office; 1996a. p. 2.

Harvey PDA, McGuinness A. A guide to British medieval seals. London: British Library and Public Record Office; 1996b. p. 34.

Higgs E. Life, death and statistics: civil registration, censuses and the work of the General Register Office, 1837-1952. Hatfield: Local Population Studies; 2004a. p. 1-44.

Higgs E. The information state in England: the central collection of information on citizens, 1500-2000. London: Palgrave; 2004b. p. 91-7. 113-18.

Hilton RH. The decline of Serfdom in Medieval England. London: Macmillan; 1969. p. 18-9.

Hindle S. On the parish? The micro-politics of poor relief in rural England, c. 1550-1750. Oxford; 2004. p. $258-60,398$.

Hindle S. Technologies of identification under the Old Poor Law. Local Hist. 2006;36:231-2.

Identity fraud: a study. London: Cabinet Office; 2002. p. 13.

Jenkinson CH. Guide to seals in the Public Record Office. London: HMSO; 1968. p. 5.

Lamont W, Prynne W. Oxford Dictionary of National Biography, online edn. In: Goldman L, editors. 1600-1669, January 2008: http://www.oxforddnb.com/view/article/22854 (9/11/08).

Macpherson CB. The political theory of possessive individualism: hobbes to locke. Oxford: Clarendon; 1962.

Muldrew C. The economy of obligation. The culture of credit and social relations in early modern England. London: Macmillan; 1998. p. 236.

New banking moves to counter giro. The Times. Tuesday, Jan. 17, 1967, p. 14.

Snell KDM. Settlement, poor law, and the rural historian: new approaches and opportunities. Rural Hist. 1992;3:145-72.

Snell KDM. The culture of local xenophobia. Soc Hist. 2003;28:1-30.

Social Security Office. How to prove your identity for social security. Leeds: Social Security Office; 2003.

Solove DJ. The digital person; technology and privacy in the information age. London: New York University Press; 2004. p. 115.

Svendsen L. A philosophy of fear. London: Reaktion Books; 2008.

Torpey J. The Great War and the birth of the modern passport system. In: Caplan J, Torpey J, editors. Documenting individual identity: the development of state practices in the modern world. Oxford: Princeton University Press; 2001. p. 256-70.

Vine R. Why the banks have gone in for automation. The Banker. 1967;CXVII:501-7.

Vivian S. History of national registration. London: Cabinet Office Historical Branch; 1951. p. 160.

Williams R, Johnson P, Martin P. Genetic information \& crime investigation: social, ethical and public policy aspects of the establishment, expansion and police use of the national DNA Database. Durham: School of Applied Social Sciences, University of Durham; 2004. 